\title{
Influence of Codium tomentosum Extract in the Properties of Alginate and Chitosan Edible Films
}

\author{
Ana Augusto ${ }^{1, *(\mathbb{1})}$, Juliana R. Dias ${ }^{2,3,4}$, Maria J. Campos ${ }^{1}{ }^{(\mathbb{D}}$, Nuno M. Alves ${ }^{1}$, Rui Pedrosa ${ }^{1}$ and \\ Susana F. J. Silva ${ }^{1}$ \\ 1 MARE-Marine and Environmental Sciences Centre, ESTM, Instituto Politécnico de Leiria, \\ 2520-641 Peniche, Portugal; mcampos@ipleiria.pt (M.J.C.); nuno.alves@ipleiria.pt (N.M.A.); \\ rpedrosa@ipleiria.pt (R.P.); susana.j.silva@ipleiria.pt (S.F.J.S.) \\ 2 Centre for Rapid and Sustainable Product Development (CDRsp), Instituto Politécnico de Leiria, \\ 2430-028 Marinha Grande, Portugal; juliana.dias@ipleiria.pt \\ 3 I3S-Instituto de Investigação e Inovação em Saúde, Universidade do Porto, 4200-135 Porto, Portugal \\ 4 INEB-Instituto de Engenharia Biomédica, Universidade do Porto, 4150-180 Porto, Portugal \\ * Correspondence: ana.l.augusto@ipleiria.pt; Tel.: +351-262-240-200
}

Received: 26 January 2018; Accepted: 27 March 2018; Published: 1 April 2018

\begin{abstract}
The growing search for natural alternatives to synthetic food packaging materials and additives has increased, and seaweed extracts' bioactivity has made them suitable candidates for incorporation in novel edible films. This study aims to investigate the effect of Codium tomentosum seaweed extract (SE) incorporation in alginate and chitosan edible films. Alginate- and chitosan-based films with and without the incorporation of $0.5 \%$ SE were characterized according to their physical, optical, mechanical, and thermal properties. Seaweed extract incorporation in chitosan films resulted in an increase of film solubility (50\%), elasticity $(18 \%)$, and decrease of puncture strength $(27 \%)$ and energy at break (39\%). In alginate films, the extract incorporation significantly decreased film solubility $(6 \%)$, water vapour permeability $(46 \%)$, and elasticity $(24 \%)$, and had no effect on thermal properties. Depending on the type of application, the addition of SE in edible films can bring advantages for food conservation.
\end{abstract}

Keywords: packaging materials; edible films; seaweeds; chitosan; alginate; natural; additive

\section{Introduction}

In recent decades, the use of edible films as a bio-based food packaging has become increasingly relevant for researchers and the food industry. Edible films can act as a selective barrier to water, oxygen, and carbon dioxide transfer and solute movements, forming a thin layer of material between the food matrix and the environment. The incorporation of active substances within the film matrix allows additional product shelf-life extension [1,2], since film functionality can change with the nature of added components [3].

Chitin is the most abundant naturally occurring amino-polysaccharide, is a by-product from the crustacean industries, and its deacetylation produces chitosan. Chitosan is an edible and biodegradable polysaccharide with attractive characteristics-namely, high antimicrobial and antifungal activities [2,4,5]. Chitosan films are an environmentally friendly option for food packaging, and are known to have a high resistance to breakage and elasticity [6,7], two important characteristics for food packaging materials.

Alginate is a polysaccharide composed by glucuronic and mannuronic acid units extracted from brown seaweeds (class Phaeophyceae) and widely used in the food industry [3,8,9]. Alginate food applications are mainly based on the unique colloidal properties that allow its gel-forming ability 
through cation binding [9]. Despite the ability to form strong films, alginate films exhibit poor water resistance due to the material's hydrophilic nature [10].

Edible seaweeds are a widespread and commercially valuable resource in food, fodder, and pharmaceutical industries, and as soil conditioner products [11]. They are also an important source of natural additives, such as antioxidants [12], antimicrobials, and polysaccharides [13]. Edible seaweeds are rich in bioactive metabolites that are not produced by terrestrial plants [14], and constitute a good source of natural additives for edible film incorporation. Despite the large number of studies in the literature regarding edible seaweed extracts [15], limited information exists concerning the extract of the edible seaweed Codium tomentosum (SE) [16-18]. A recent study showed that the immersion of minimally processed Fuji apple in a solution containing $0.5 \%$. tomentosum extract minimized apple browning in the refrigerated product for 20 days and inhibited peroxidase (POD) and polyphenoloxidase (PPO) activities [18].

The present work aims to assess how $C$. tomentosum extract incorporation in alginate and chitosan edible films influences the polymers' barrier, optical, mechanical, and thermal properties. Alginate and chitosan films were selected, as these are widely used edible polymers in the food industry. The results of the present work are of relevant importance to determine the potential success of the incorporation of $C$. tomentosum seaweed extract in edible films, addressing public concerns to reduce the use of traditional food packaging, such as plastic films, and food waste, and longer food shelf-life.

\section{Materials and Methods}

\subsection{Chemicals}

Alginic acid sodium salt, low viscosity was purchased from Alfa Aesar GmbH (Karlsrube, Germany) and used as received. Commercial chitosan from shrimp shells ( $\geq 75 \%$ deacetylation degree, Mw 50-190 kDa), 6-hydroxy-2,5,7,8-tetramethylchroman-2-carboxylic acid (Trolox), and 2,2'-azobis (2-methylpropionamidine) dihydrochloride $(\mathrm{AAPH})$ were purchased from Sigma-Aldrich Co. (Steinheim, Germany).

\subsection{Seaweed Collection and Seaweed Extract Preparation}

Fresh C. tomentosum samples were collected in Peniche, Portugal in September 2012. Extractions were performed using water/ethanol as the extraction solvents [18]. The dried extract was stored at $-80^{\circ} \mathrm{C}$ (ultra-low freezer, Thermo Fisher Scientific, Waltham, MA, USA) until further analyses.

\subsection{Extract Characterization}

SE moisture content was determined with an automatic moisture analyser (model HB 43-S; Mettler Toledo, Giesen, Germany). Ash content was quantified following the procedures adopted by the Association of Analytical Communities (AOAC International) [19]. Nitrogen content was determined by the Kjeldahl method using a conversion factor of 6.25 (Kjeltech 2006, Foss Tecator, Hillerod, Denmark). Total lipid extraction method was achieved as previously described in the literature [20], following a dry matter basis. Carbohydrate content was estimated by difference of all other components. To estimate total phenolic content, the oxygen radical absorbance capacity assay (ORAC) of the seaweed extract was determined [21]. The ORAC value was calculated and expressed as micromoles of Trolox equivalents (TEs) per gram extract ( $\mu \mathrm{mol} \mathrm{of} \mathrm{TE} \mathrm{g}^{-1}$ extract) using the calibration curve of Trolox.

\subsection{Film Preparation}

Alginate film-forming solutions (FFSs) were prepared by suspending $1 \%(w / v)$ of alginate (A) in distilled water at $70{ }^{\circ} \mathrm{C}$ until complete dissolution. After cooling to $45^{\circ} \mathrm{C}$ at room temperature, glycerol was added at $1 \%(v / v)$ of the total volume with gentle stirring for $15 \mathrm{~min}$. The same procedure 
was used for the preparation of FFS with SE, but the addition of $0.5 \%(w / v)$ seaweed extract (AE) was made before alginate addition.

Chitosan $(1 \% w / v)$ was dissolved into $1 \%(w / v)$ citric acid solution (C). The mixture was stirred continuously at room temperature for 8 hours to obtain a homogeneous solution. Tween $80(0.1 \% v / v)$ was added as plasticizer after homogenization followed by filtration to the removal of undissolved material. FFS with SE incorporation was performed with the same procedure, but with the addition of $0.5 \%(w / v)$ seaweed extract (CE) before chitosan. $C$ and $C E$ were degassed prior to drying by keeping the solution in a vacuum oven for $3 \mathrm{~h}$ to remove the trapped air bubbles.

FFS were cast into dishes $(\varnothing 120 \mathrm{~mm})$ assuring a surface density of solids in the dry films of $70 \mathrm{~g} \mathrm{~m}^{-2}$ in all formulations and dehydrated in a tray dryer (Armfield Tray Drier Type Uop8-A, Ringwood, UK) until constant weight was reached (air flow rate of $0.70 \mathrm{~m} \mathrm{~s}^{-1}, 23^{\circ} \mathrm{C}$, and relative humidity (RH) $55 \%$ ). Dry films were preconditioned in desiccators (containing gel silica) at $20 \pm 2{ }^{\circ} \mathrm{C}$ prior to testing.

\subsection{Film Characterization}

\subsubsection{FTIR-ATR}

The Fourier transform infrared spectroscopy attenuated total reflection (FTIR-ATR) technique was used to evaluate the functional groups of the materials and to detect possible changes with the seaweed extract incorporation. The FTIR analysis was carried out using an Alpha-P FTIR-ATR spectrometer (Bruker Optik GmbH, Ettlingen, Germany) in a range of $4000-400 \mathrm{~cm}^{-1}$, at a $4 \mathrm{~cm}^{-1}$ resolution with 64 scans.

\subsubsection{Film Thickness and Light Absorption}

All films were visually inspected for homogeneity. Films thickness was determined using a manual micrometer (Mettler Toledo Ltd., Leicester, UK) with an accuracy of $0.001 \mathrm{~mm}$, and an average of 15 measurements taken at different locations in films was considered.

Film light barrier properties were determined using transparency values $(\mathrm{T})$ calculated using the film absorption, measured at $550 \mathrm{~nm}\left(\mathrm{~A}_{550}\right)$ with a UV-160 UV-vis spectrophotometer (Thermo Electron Corporation, Waltham, MA, USA) and film thickness (mm) (x) [22]:

$$
\mathrm{T}=\mathrm{A}_{550} / \mathrm{x}
$$

\subsubsection{Surface Color Measurement}

Film colour was determined by a colorimeter Konica Minolta CR-400 (Minolta INC., Tokyo, Japan). The equipment was calibrated using a standard white reflective plate. CIELab scale was used with colour parameters expressed in terms of: $L^{*}$ (lightness), $a^{*}$ (red/green), and $b^{*}$ (yellow/blue). Nine measurements for each sample were taken, placing the film sample over the standard white plate $\left(L^{*}=95.38 ; a^{*}=-0.16 ; b^{*}=2.48\right)$. The Euclidean distance between two points was determined with the colour difference equation $(\Delta \mathrm{E})$, and whiteness index $(\mathrm{WI})$ was calculated [23].

\subsubsection{Moisture Content and Film Solubility}

Film moisture content was determined with an automatic moisture analyser. Film solubility was determined by a gravimetric procedure $[7,24]$. The initial film dry weight $\left(\mathrm{W}_{\mathrm{i}}\right)$ and final dry weight $\left(\mathrm{W}_{\mathrm{f}}\right)$ were determined after a drying process at $105^{\circ} \mathrm{C}$ for $24 \mathrm{~h}$. Initial dried samples were immersed in $30 \mathrm{~mL}$ of distilled water and gently shaken for $24 \mathrm{~h}$, followed by a drying process to determine $\mathrm{W}_{\mathrm{f}}$. Film solubility (FS\%) was calculated using the following equation:

$$
\mathrm{FS} \%=\left(\mathrm{W}_{\mathrm{i}}-\mathrm{W}_{\mathrm{f}}\right) / \mathrm{W}_{\mathrm{i}} \times 100
$$




\subsubsection{Water Vapour Permeability (WVP)}

Film water vapour permeability was measured gravimetrically $[7,25]$, with slight adaptations to hydrophilic edible films matrix. Films without defects were sealed to a cup mouth (cell) containing $100 \mathrm{~mL}$ of distilled water $\left(100 \% \mathrm{RH}, 2000 \mathrm{~Pa}\right.$ vapour pressure at $\left.23^{\circ} \mathrm{C}\right)$ with an exposed film area of $6 \mathrm{~cm}^{2}$. Test cups with films were placed in contact with an atmosphere at $23^{\circ} \mathrm{C}$ and $75.7 \% \mathrm{RH}(2119.6 \mathrm{~Pa}$ vapour pressure); after $1 \mathrm{~h}$ for atmosphere adaptation, the cells were weighed $( \pm 0.0001 \mathrm{~g})$ at intervals of $30 \mathrm{~min}$ during $4 \mathrm{~h}$. The measured WVP $\left(\mathrm{kg} \mathrm{Pa}^{-1} \mathrm{~s}^{-1} \mathrm{~m}^{-1}\right)$ of the films was determined $[7,23]$.

\subsubsection{Surface Film Wettability}

The sessile drop method was used to estimate the surface hydrophobicity of the films. The water contact angle was determined to evaluate the film's surface wettability, as well as the influence of SE extract on its properties. The static contact angle $(\theta)$ was measured with an optical tensiometer (Paralab Company, model Theta, Gondomar, Portugal) using water.

Before measurements, samples were pre-conditioned at RH $0 \%$. The tests were made at $23{ }^{\circ} \mathrm{C}$ within the first $10 \mathrm{~s}$ (12 Frames Per Second) after dropping the solvent (distilled water) onto film surfaces, to avoid variations due to solvent penetration onto the specimens.

\subsubsection{Moisture Sorption Isotherms}

Water vapour sorption isotherms were drawn based on the static method $[24,26]$ by keeping film samples at $23{ }^{\circ} \mathrm{C}$ in desiccators with saturated salt solutions $\left(\mathrm{MgCl}_{2}, \mathrm{KCl}, \mathrm{Mg}\left(\mathrm{NO}_{3}\right)_{2}, \mathrm{NaCl}\right.$, and $\left.\mathrm{KNO}_{3}\right)$ with water activity $\left(a_{\mathrm{w}}\right)$ ranging from 0.330 to 0.930 , until equilibrium was reached. Moisture content at equilibrium was determined by drying the film at $105^{\circ} \mathrm{C}$ for $48 \mathrm{~h}$.

\subsubsection{Mechanical Properties}

Puncture tests were run as reported in literature [27] using a texture analyser Model TA.XT.plus (Stable Micro Systems, Surrey, UK) controlled by the Texture Exponent Software 32 (Stable Micro Systems, Surrey, UK). A cylindrical puncture probe (2 mm diameter; Stainless P/2) was used to determine the percentage of elongation at break. Nine replicates of each film were performed.

\subsubsection{Thermal Analysis}

Thermal properties and stability were determined using the Simultaneous Thermal Analyser, STA 6000 system (PerkinElmer, Boston, MA, USA). For this, 3-4 mg samples were placed in ceramic pans and tested under dry nitrogen purge (flow rate of $20 \mathrm{~mL} \mathrm{~min}^{-1}$ ). Samples were submitted to temperature of $30^{\circ} \mathrm{C}$ to $350{ }^{\circ} \mathrm{C}$ at a rate of $10{ }^{\circ} \mathrm{C} \mathrm{min}-1$. Melting endotherm peaks and peak areas were used to determine melting temperatures $(\mathrm{Tm})$ and enthalpies of fusion $\left(\Delta \mathrm{H}_{\mathrm{m}}\right)$, respectively. Indium and silver samples were used as calibration standards.

\subsection{Data Statistical Analysis}

All measurements were performed in triplicate, except when stated otherwise. One-way analysis of variance (ANOVA), followed by Fishers Least Significant Difference (LSD) test for multiple comparisons of group means were applied to determine significant differences between films $(\mathrm{A}, \mathrm{AE}$, $\mathrm{C}$, and CE). All data were checked for normality and homoscedasticity. This procedure was applied for all measurements under study. Where applicable, results are presented as mean \pm standard deviation (SD). For all statistical tests, the significance level was set at $p \leq 0.05$. All calculations were performed with IBM SPSS Statistics 21 (IBM, New York, NY, USA). 


\section{Results and Discussion}

\subsection{C. tomentosum Extract Characterization}

The proximal composition of $C$. tomentosum extract is shown in Table 1 . The relatively higher ash proportion in seaweed extract (SE) (approx. 74\%) can largely be accounted for by the lower moisture content, which can probably be attributed to the hygroscopic nature of the SE [28].

Table 1. Moisture, protein, ash, fat, and carbohydrate contents (\% dry weight), and peroxyl radical scavenging activity (ORAC) of seaweed extract.

\begin{tabular}{cc}
\hline Test & Seaweed Extract \\
\hline Moisture (\%) & $6.4 \pm 1.2$ \\
Protein (\%) & $2.07 \pm 0.06$ \\
Ash (\%) & $73.97 \pm 0.33$ \\
Fat (\%) & $1.17 \pm 0.06$ \\
Carbohydrate (\%) ${ }^{\text {a }}$ & 16.39 \\
ORAC (Trolox equivalent, $\mu \mathrm{mol} \mathrm{g}^{-1}$ extract) & $5.99 \pm 0.07$ \\
\hline
\end{tabular}

Results are the mean \pm standard deviation (SD) $(n=3)$. ${ }^{a}$ Determined by difference of all other components.

The peroxyl scavenging activity of $C$. tomentosum extract-as measured by the ORAC assay-was approximately 100 times lower than the values presented in other studies [16] when methanol and dichloromethane were used as extraction solvents. However, the use of extraction solvents for food applications has legal restrictions, and ethanol is one of the authorized solvents according to the European Directive 2009/32/EC [29].

\subsection{Thickness, Surface Color, and Light Absorption}

The thickness of the formulated films ranged from 0.03 to $0.05 \mathrm{~mm}$ (Table 2). Alginate and chitosan films were transparent and homogeneous, and the incorporation of the SE resulted in heterogeneous regions in both films. Under high humidity conditions (e.g., laboratory facilities), alginate films absorbed moisture, becoming difficult to handle.

Table 2. Colour parameters, colour difference $(\Delta \mathrm{E})$, whiteness index $(\mathrm{WI})$, and transparency $(\mathrm{T})$, thickness $(\mathrm{mm})$, moisture $(\%)$, water solubility $(\%)$, water vapour permeability (WVP), and contact angle $\left(^{\circ}\right)$ of alginate and chitosan films with and without seaweed extract (SE).

\begin{tabular}{ccccc}
\hline Test & Alginate & Alginate + SE & Chitosan & Chitosan + SE \\
\hline Thickness $(\mathrm{mm})$ & $0.05 \pm 0.02$ & $0.03 \pm 0.01$ & $0.05 \pm 0.01$ & $0.06 \pm 0.01$ \\
$L^{*}$ & $92.68 \pm 0.68$ & $92.87 \pm 0.15$ & $93.89 \pm 0.32$ & $93.65 \pm 0.93$ \\
$a^{*}$ & $-0.44^{\mathrm{A}} \pm 0.02$ & $-0.53^{\mathrm{B}} \pm 0.03$ & $-0.46^{\mathrm{A}} \mathrm{C} \pm 0.05$ & $-0.66^{\mathrm{D}} \pm 0.11$ \\
$b^{*}$ & $6.75^{\mathrm{A}} \pm 0.17$ & $9.42^{\mathrm{B}} \pm 0.39$ & $3.96^{\mathrm{C}} \pm 0.21$ & $5.20^{\mathrm{D}} \pm 0.73$ \\
$\Delta \mathrm{E}^{\#}$ & $5.09^{\mathrm{A}} \pm 0.42$ & $7.40^{\mathrm{B}} \pm 0.40$ & $2.13^{\mathrm{C}} \pm 0.33$ & $3.36^{\mathrm{D}} \pm 0.85$ \\
WI & $91.69^{\mathrm{A}} \pm 0.34$ & $88.17^{\mathrm{B}} \pm 0.37$ & $92.70^{\mathrm{C}} \pm 0.35$ & $91.73^{\mathrm{A}, \mathrm{D}} \pm 0.87$ \\
$\mathrm{~T}$ & $2.4^{\mathrm{A}} \pm 0.1$ & $13.1^{\mathrm{B}} \pm 0.4$ & $3.1^{\mathrm{C}} \pm 0.3$ & $2.5^{\mathrm{D}} \pm 0.1$ \\
Moisture $(\%)$ & $24.86 \pm 0.01$ & $28.29^{\mathrm{B}} \pm 0.01$ & $9.56 \pm 0.01$ & $10.06 \pm 0.01$ \\
Film solubility $(\%)$ & $90.68^{\mathrm{A}} \pm 1.79$ & $86.13^{\mathrm{B}} \pm 1.06$ & $23.83^{\mathrm{C}} \pm 2.96$ & $45.84^{\mathrm{D}} \pm 2.72$ \\
WVP $\left(\times 10^{-16} \mathrm{~kg} \mathrm{~Pa}^{-1} \mathrm{~s}^{-1} \mathrm{~m}^{-1}\right)$ & $0.939^{\mathrm{A}} \pm 0.317$ & $0.514^{\mathrm{B}} \pm 0.26$ & $1.18^{\mathrm{A}} \pm 0.0071$ & $1.22^{\mathrm{A}} \pm 0.0085$ \\
Contact angle $\left(^{\circ}\right)$ & $37.70^{\mathrm{A}} \pm 0.15$ & $8.9^{\mathrm{B}} \pm 0.30$ & $78.58^{\mathrm{C}} \pm 0.27$ & $21.80^{\mathrm{D}} \pm 0.57$ \\
\hline
\end{tabular}

Data shown are the means ( $\pm \mathrm{SD})$ ( $n=9$ for colour parameters, $n=15$ for thickness; $n=3$ for the other tests). $\mathrm{A}, \mathrm{B}, \mathrm{C}, \mathrm{D}$ show significant differences in each test $(p<0.05$, one-way analysis of variance (ANOVA), least significant difference (LSD) test). ${ }^{\#}$ colour differences between the standard white plate and film samples (see Section 2.5.3).

The optical properties of films are an important indicator of film suitability as an edible coating, as it interferes with the product appearance and may lead to consumer rejection [23,30]. The results of the film colour measurements are shown in Table 2. All films were transparent with a slight yellowish 
colour, in agreement with the measured $b^{*}$ value. The addition of SE resulted in increased $b^{*}$ values for both types of film $(p<0.05)$. Previous studies mentioned similar results, such as an increase in $b^{*}$ values in fish gelatin films with the incorporation of SE [31]. Red/green $\left(a^{*}\right)$, yellow/blue $\left(b^{*}\right)$ coordinates, and total colour differences significantly increased $(p<0.05)$ with the incorporation of SE in both alginate and chitosan-based films. The $a^{*}$ value has been used as a physical parameter to represent greenness in colour measurements [32]. Chlorophylls-the pigments responsible for the characteristic green colour of plants and which are present in C. tomentosum-are most likely responsible for the observed variation in $a^{*}$ value. Colour changes in the resulting film may be due to pigments remaining in the SE. As a consequence of $L^{*}, a^{*}$, and $b^{*}$ changes, the whiteness index values decreased with the addition of SE $(p<0.05)$.

The addition of SE to alginate films increased $t$ values $(p<0.05)$, which indicates a lower degree of film transparency, corresponding to higher light absorption and consequently a higher film opacity [29,33]. On the contrary, the addition of SE to chitosan films decreased $t$ values $(p<0.05)$, increasing film transparency appearance (Table 2).

\subsection{FTIR-ATR Analysis}

Through the interpretation of films' FTIR spectra, it is possible to identify specific functional groups and therefore investigate possible interactions between the polysaccharides (alginate or chitosan) and the incorporated SE. FTIR spectra of the different formulated films and the seaweed extract (SE) are presented in Figure 1.

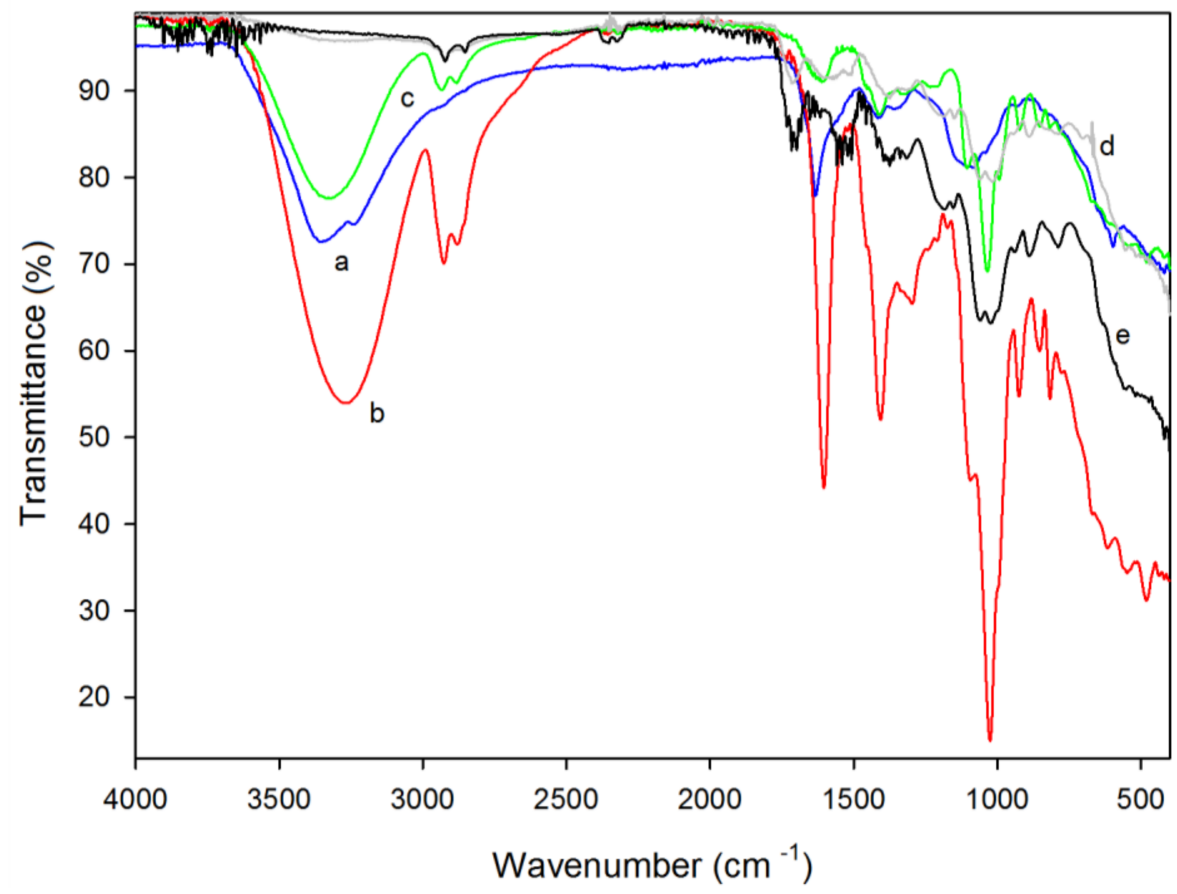

Figure 1. Fourier transform infrared spectroscopy attenuated total reflection (FTIR-ATR) spectrum of the (a) C. tomentosum seaweed extract (blue line) and the different tested films: (b) $1 \%$ alginate (red line), (c) $1 \%$ alginate with $0.5 \%$ of $C$. tomentosum seaweed extract (green line), (d) $1 \%$ chitosan (grey line), and (e) $1 \%$ chitosan with $0.5 \%$ of $C$. tomentosum seaweed extract (black line).

The FTIR spectra of $C$. tomentosum extract (Figure 1a) showed absorption bands at $1100-930 \mathrm{~cm}^{-1}$, which are normally present in seaweed polysaccharide standards and can represent both $\mathrm{C}-\mathrm{C}$ and $\mathrm{C}-\mathrm{O}$ pyranoid ring stretching and C-O-C glycosidic bond stretching [28]. The presence of proteins in the SE could be explained by the above-mentioned bonds, typically present in protein spectra [34]. As seen in Table 1, SE had $2 \%$ protein. SE showed a strong transmission band at $1630 \mathrm{~cm}^{-1}$, related to the 
stretching vibration of the $(\mathrm{NH}) \mathrm{C}=\mathrm{O}$ group - a group also observed in extracts of Codium capitatum, a seaweed from the same genus of $C$. tomentosum [34]. In these spectra, it is also possible to observe a broad band at $3357 \mathrm{~cm}^{-1}$ that could be related to the presence of polysaccharides in SE. The possible presence of the sulphated polysaccharide fucoidan in the SE could be associated to the sulphate $\left(\mathrm{SO}_{4}\right)$ and methyl $\left(\mathrm{CH}_{3}\right)$ group bands signals observed at $1414 \mathrm{~cm}^{-1}$ and $1360 \mathrm{~cm}^{-1}$, respectively $[35,36]$. The use of fucoidan as a nutraceutical and food supplement is under study, and therefore the presence of this polysaccharide in C. tomentosum extract can be an advantage-mostly due to its antioxidant and antibacterial properties [35].

The alginate film exhibited four outstanding bands corresponding to a COO- (asymmetric) stretching at $1603 \mathrm{~cm}^{-1}$, a COO- (symmetric) stretching band at $1407 \mathrm{~cm}^{-1}$, and a C-O-C stretching band at $1025 \mathrm{~cm}^{-1}$ (Figure 1b) $[8,37]$ and the presence of bands at $817 \mathrm{~cm}^{-1}$ on the alginate films spectra, which indicates the presence of mannuronic acid [37].

A broad band at $3273 \mathrm{~cm}^{-1}$ representing hydroxyl groups (HO-) was also observed. The - $\mathrm{CH}$ vibration band occurs at $2928 \mathrm{~cm}^{-1}$, which can be overlapped with the COO- vibration bands [8,38]. No significant differences were observed between the FTIR spectra of alginate film with and without seaweed extract in terms of wavenumber absorbance (Figure 1c). A slight reduction of the bands size in the former bands was observed with SE incorporation. In both spectra, it was possible to identify the vibration bands from $\mathrm{COO}, \mathrm{CH}, \mathrm{C}-\mathrm{O}, \mathrm{OH}$, and $\mathrm{C}-\mathrm{O}-\mathrm{C}$ groups.

The FTIR spectrum of the chitosan film (Figure 1d) showed a C-H stretching between $2922 \mathrm{~cm}^{-1}$ and $2920 \mathrm{~cm}^{-1}$ and bands at $1186 \mathrm{~cm}^{-1}$ and $1017 \mathrm{~cm}^{-1}$, indicating the presence of a free amino group at the $\mathrm{C}_{2}$ position of glucosamine (a major group present in chitosan). The presence of the first $\mathrm{C}-\mathrm{H}$ stretching was also observed in chitosan films with seaweed extract (Figure 1e) at the same range of wavenumber; the second range of bands were also present, but with a minor intensity. The absence of a broad band around $1610 \mathrm{~cm}^{-1}$ (representing acetylated amino groups) in both C and CE spectra is associated with a high degree of deacetylation, which agrees with sample specifications $(\geq 75 \%$ deacetylation degree) [39]. A broad band at $1712 \mathrm{~cm}^{-1}$ might be related to carbonyl vibration of the carboxylic acid [39].

SE interactions with alginate and chitosan matrices were mainly reflected in the bands' areas, which represent the extent of interaction between them. In all cases, the addition of SE led to a variation in area, reflecting different intensities of the chemical bonds established in these materials. These differences may influence the following described film properties.

\subsection{Moisture Content and Film Solubility}

Film hydrophobicity is related to the amount of water present in films; the more hydrophilic the film, the higher the moisture content [23]. Table 2 shows the moisture content of the studied edible films. Alginate-based films showed the highest values of moisture (24-28\%), with chitosan-based films presenting significantly lower moisture contents (9-10\%) (environment RH of 75\%).

Film solubility determines the biodegradability of films when used as food packaging, as well as their functionality as a water barrier [5]. Higher water solubility indicates lower water resistance. A and AE films (alginate-based films) showed the highest values of water solubility (86-90\%) (Table 2), indicating the high hydrophilic character of alginate films in the presence of water (also reported in literature [23]), and lower film integrity in high-humidity environments [10]. The addition of SE to alginate films resulted in a decrease in water solubility $(6 \%)(p<0.05)$ (Table 2), perhaps due to the presence of hydrogen bond and hydrophobic interaction of protein in the film matrix [31]. Studies also showed that the extract of the seaweed Turbinaria ornata decreased the solubility of fish gelatin-based films [31], presenting lower values of solubility when compared to alginate-based films in the present study. As shown in Table 2, chitosan film had low water solubility, which was expected given that chitosan is mainly soluble in organic solutions and in acids such as hydrochloric, phosphoric, and nitric acid at $\mathrm{pH}$ bellow 6.5 [40]. The incorporation of SE into chitosan films resulted in a significant increase of water solubility $(p<0.05)$; researchers also reported an improvement of the water solubility of 
chitosan films with the incorporation of tea extracts [41]. In this study, the interaction between chitosan and SE could induce a decrease in the cross-linking degree of intermolecular chains in the matrix, thus resulting in the observed higher solubility.

\subsection{Water Vapor Permeability (WVP)}

Films' WVP at a relative humidity gradient of 100:75 are shown in Table 2. Measured values ranged from $0.514-1.22 \times 10^{-16} \mathrm{~kg} \mathrm{~Pa}^{-1} \mathrm{~s}^{-1} \mathrm{~m}^{-1}$. The WVP values of the analysed alginate films were lower than the values presented in other studies [3,42]. These differences might be caused by different film preparation techniques (concentration and drying technique) and WVP measuring conditions (different RH gradient). The addition of SE caused a 45\% $(p<0.05)$ reduction in the WVP of alginate films, possibly as a result of changes in the degree of crosslinkage that led to a reduction in the polymeric chain mobility. This effect was also reported in alginate films with higher concentrations of calcium [42]. Similar behaviour of gelatin films with T. ornata extract inclusion was observed in previous works [31], possibly due to the presence of phenolic compound in the SE that might enhance the crosslinkage of gelatin. SE incorporation seems to interfere in the hydrophilic portion of films, and consequently in the hydrophilic/hydrophobic ratio, affecting water vapour transfer that generally occurs in the hydrophilic zone of the films structure [43]. The results also showed that the incorporation of SE did not significantly influence the WVP of chitosan films $(p>0.05)$. Furthermore, WVP values were in the range of WVP obtained for similar films (WVP rate of $1.53 \mathrm{~g} \mathrm{~h}^{-1} \mathrm{~mm}^{-1} \mathrm{~m}^{-1} \mathrm{kPa}^{-1}$ ), reflecting the low water barrier characteristics of chitosan films [44]. The obtained values for WVP were far from the ones presented by petroleum-based polymers commonly used in food packaging, which have a WVP rate of $9.14 \times 10^{-13} \mathrm{~g} \mathrm{~m}^{-1} \mathrm{~s}^{-1} \mathrm{~Pa}^{-1}$ [44], indicating that the studied films still need further improvements if they are to be used as an alternative to these materials.

\subsection{Surface Film Wettability}

Water contact angle is an indicator of film surface hydrophilicity; the lower the contact angle, the greater the material surface hydrophilicity [45]. The contact angle between water droplets and the surfaces of alginate and chitosan films were analysed (Table 2). Chitosan films (C) showed a higher contact angle $\left(\theta=78^{\circ}\right)$ compared with the remaining films. Influences of SE incorporation on contact angle values was verified, with a significant decrease $(p<0.05)$ of values in both types of films. The use of a polar solvent (water, relative polarity of 1 ) and a moderately polar solvent (ethanol, relative polarity of 0.654) [46] in the extraction can lead to the extraction of polar compounds. The SE incorporation in alginate and chitosan increased the hydrophilicity and consequently the film wettability, justifying the contact angle of $8^{\circ}$ in $\mathrm{AE}$ films and $21^{\circ}$ in $\mathrm{CE}$ films. Even though SE incorporation led to films with high hydrophilicity and concomitant increase in WVP, the application of this type of solution in food matrixes can be efficient, as high values of film wettability are related to a high surface coating capacity, enabling easier application on the food surface [45].

The contact angle results were in good agreement with the obtained moisture values (Table 2); higher moisture content led to lower contact angles, indicating a greater ability to absorb water and thus explaining the high hydrophilicity.

\subsection{Moisture Sorption Isotherms}

Sorption isotherms of the films are presented in Figure 2 ( 0.34 to $0.94 a_{\mathrm{w}}$ ranges). The initial moisture content of each film was different (Table 2), which means that the driving force of the sorption process was different, resulting in distinct curves. Higher values of moisture at equilibrium in alginate-based films were expected, since alginate is a hydrophilic polymer prone to absorb water vapour present in the atmosphere. High relative humidity values can have a negative effect on the application of alginate based films in food packaging systems, as it can lead to film solubilisation, causing failures in its structure and compromising its barrier properties [3]. Chitosan-based films 
( $C$ and $C E$ ) presented lower moisture values at equilibrium since chitosan had a low water solubility, preventing water retention in the film and resulting in lower moisture values.

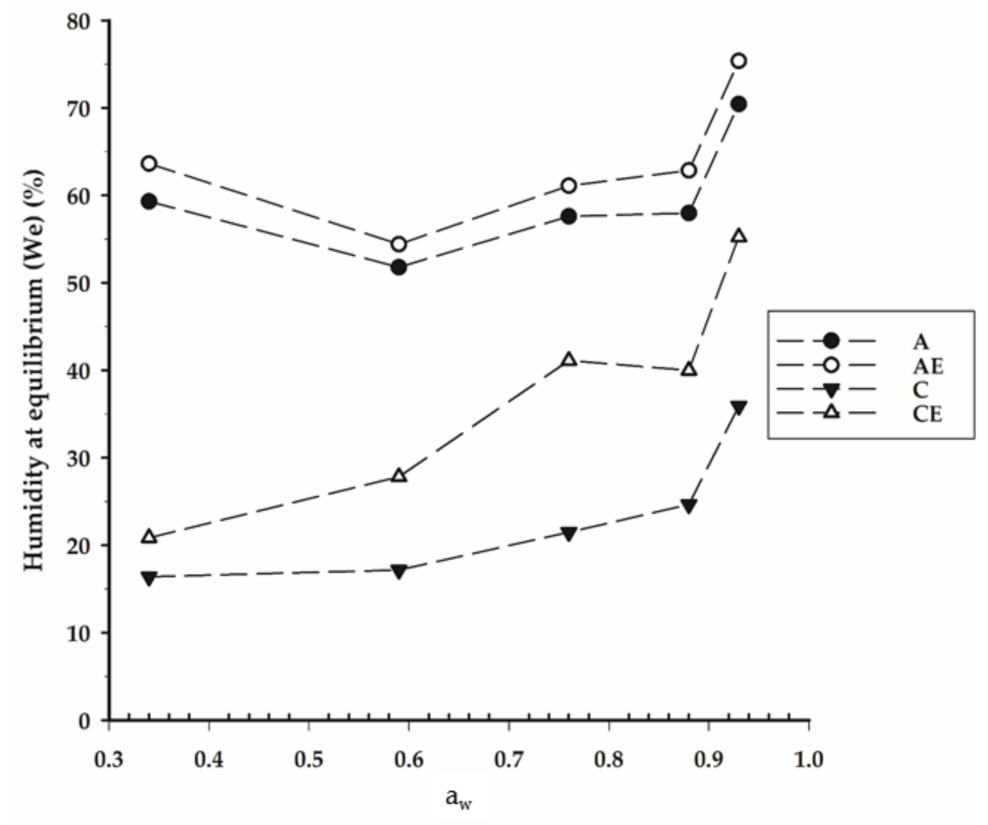

Figure 2. Moisture sorption isotherms of alginate without (A) and with seaweed extract (AE), chitosan without $(\mathrm{C})$ and with extract $(\mathrm{CE})$ films at $21 \pm 2{ }^{\circ} \mathrm{C}$. Data shown are the means $(n=3) . a_{\mathrm{w}}$ : water activity.

The incorporation of SE had no effect on the sorption isotherm of alginate-based film. On the contrary, in chitosan films, SE incorporation resulted in higher equilibrium moisture for all $a_{\mathrm{w}}$ tested in chitosan based films. This observation agrees with the results regarding the effect of SE in chitosan films, where extract incorporation significantly increased the film solubility and decreased contact angle (Table 2).

\subsection{Mechanical Properties}

The mechanical properties of the studied films are presented in Table 3. Chitosan films with SE showed the highest elongation at break when compared to other film formulations, indicating higher film extensibility and mechanical strength. Extensibility and mechanical strength are two important material characteristics, related to the capacity of films to tolerate external stress and maintain integrity and barrier properties when applied as food packaging [7]. The addition of SE to chitosan films increased the elongation at break $(p<0.05)$, decreasing the puncture strength $(p<0.05)$ and energy at break $(p<0.05)$. These results were in contrast with those presented in other studies, where the elongation at break significantly decreased with the addition of antimicrobial compounds [41] and tea extracts into chitosan films [47]. These changes in mechanical properties could indicate that film structure softens, forming a more flexible film and consequently higher elongation values when subjected to tension and mechanical stress. SE could act as a plasticizer in film formulation, increasing the molecular mobility of the polymers [48] and resulting in the increase of elongation at break and the decrease of puncture strength. Mechanical properties of $C E$ films were in agreement with the results of moisture and film solubility (Table 2). The incorporation of SE in alginate films led to a $23 \%$ decrease of elongation at break values $(p<0.05)$, increasing puncture strength and energy at break values. In this case, the incorporation of SE had the opposite effect of when applied on chitosan films, resulting in a film of higher brittleness. An equilibrium between the degree of polymer crosslinking and seaweed extract addition is required for better film workability characteristics, which changes film properties such as the solubility in water, affecting film brittleness (observed in Table 2) [48]. 
Table 3. Mechanical properties of alginate and chitosan films with and without seaweed extract (SE). Differential scanning calorimetry (DSC) data of films and seaweed extract.

\begin{tabular}{cccccc}
\hline Test & Alginate & Alginate + SE & Chitosan & Chitosan + SE & Seaweed Extract \\
\hline Elongation at break (\%) & $69.81^{\mathrm{A}} \pm 4.06$ & $53.68^{\mathrm{B}} \pm 2.92$ & $60.81^{\mathrm{C}} \pm 7.03$ & $74.60^{\mathrm{D}} \pm 4.60$ & - \\
Puncture Strength $\left(\mathrm{N} \mathrm{mm}^{-2}\right)$ & $0.023^{\mathrm{A}} \pm 0.007$ & $0.029^{\mathrm{A}} \pm 0.006$ & $0.127^{\mathrm{B}} \pm 0.048$ & $0.093^{\mathrm{C}} \pm 0.027$ & - \\
Energy at break $\left.(\mathrm{N} \mathrm{s} \mathrm{mm})^{-3}\right)$ & $0.69^{\mathrm{A}} \pm 0.43$ & $1.39^{\mathrm{A}} \pm 0.94$ & $4.51^{\mathrm{B}} \pm 2.24$ & $2.76^{\mathrm{C}} \pm 1.09$ & - \\
$\operatorname{Tm}_{\left({ }^{\circ} \mathrm{C}\right)}^{*}$ & $184.22^{\mathrm{A}} \pm 1.15$ & $196.64^{\mathrm{A}, \mathrm{B}} \pm 1.89$ & $180.07^{\mathrm{A}}, \mathrm{C} \pm 0.61$ & $193.10^{\mathrm{A}} \pm 13.94$ & $144.70 \pm 0.38$ \\
$\Delta \mathrm{H}_{\mathrm{m}}\left(\mathrm{J} \mathrm{g}^{-1}\right)^{*}$ & $33.28^{\mathrm{A}} \pm 4.31$ & $2.45^{\mathrm{B}} \pm 0.10$ & $6.91^{\mathrm{B}} \pm 1.98$ & $6.20^{\mathrm{B}} \pm 3.13$ & $26.96 \pm 5.98$ \\
$\left.\operatorname{Td}^{\circ} \mathrm{C}\right)^{*}$ & $180.68^{\mathrm{A}} \pm 0.71$ & $201.05^{\mathrm{B}} \pm 4.14$ & $164.17^{\mathrm{C}} \pm 8.63$ & $187.22^{\mathrm{A}, \mathrm{D}} \pm 5.23$ & $86.62 \pm 0.64$ \\
& & & & $135.49 \pm 0.47$ \\
\hline
\end{tabular}

Data shown are the means $( \pm \mathrm{SD})\left(n=9\right.$ for mechanical properties, $n=3$ for DSC data). ${ }^{\mathrm{A}, \mathrm{B}, \mathrm{C}, \mathrm{D}}$ show significant differences in each test $\left(p<0.05\right.$, ANOVA, LSD test). ${ }^{*} \mathrm{Tm}$ : melting temperature; $\Delta \mathrm{Hm}$ : melting enthalpy; Td: degradation temperature.

\subsection{Thermal Properties}

The thermal properties of the tested alginate- and chitosan-based films and SE are summarized in Table 3. At the temperature ranges of $27-100{ }^{\circ} \mathrm{C}$ for films and $75-115^{\circ} \mathrm{C}$ for SE, it was possible to verify the first endothermic peak that could be associated with water loss $[49,50]$. The peaks in the range of $155-230{ }^{\circ} \mathrm{C}, 152-200{ }^{\circ} \mathrm{C}$, and $131-153{ }^{\circ} \mathrm{C}$ were attributed to melting transition in alginate and chitosan based films $[8,50,51]$ and $\mathrm{SE}$, respectively. The melting temperature $(\mathrm{Tm})$ of alginate and chitosan films was not affected by the addition of SE $(p>0.05)$.

SE incorporation resulted in a significant increase in degradation temperature (Td; $p>0.05)$ for both polymers $\left(21^{\circ} \mathrm{C}\right.$ in alginate, $23^{\circ} \mathrm{C}$ in chitosan). The same trend was observed in the crosslinking process of alginate films with Aloe vera [8]. Increasing degradation temperature is related to a higher thermal stability of films. SE incorporation in films resulted in an increase of melting points and temperature of degradation, indicating that these films may present more regular structures and higher packing capability or stronger inter-chain attraction [52]. This could be also correlated with the decrease of elongation at break (\%) of AE films (Table 3), indicating the presence of a rigid structure.

Despite increased thermal stability due to the incorporation of SE, in chitosan films the melting enthalpy $\left(\Delta \mathrm{H}_{\mathrm{m}}\right)$ values of the samples were lower $(p<0.05)$ when compared with the original films (Table 3). The decrease of $\Delta \mathrm{H}_{\mathrm{m}}$ values could reflect requirements of low energy to break the bonds (corroborated by the measured puncture strength and energy at break for different films shown in Table 3) when the sample was subjected to programmed heating, indicating a weak interaction between chitosan and SE [39].

The results of the thermal analysis of films are shown in Table 3. It was possible to observe two different steps: the first one at $86^{\circ} \mathrm{C}$ could be associated with the devolatilisation of the sample, and the second one could be associated with the melting temperature [53]. This pattern can be related with crystalline solids that exhibit a pseudopolymorphic behavior-a term that refers to crystalline forms with solvent molecules as an integral part of the structure [54]. To verify the presence of solvent molecules in the extract structure, it would be necessary to carry out more studies, such as differential scanning calorimetry (DSC) associated with gas chromatography or mass spectrometry. The volatilization of the sample could be also observed in $\mathrm{CE}$ films $\left(\mathrm{Td}=85^{\circ} \mathrm{C}\right)$, revealing a possible crosslinking process between chitosan and SE.

\section{Conclusions}

The addition of $C$. tomemtosum extract to alginate and chitosan films significantly affected their mechanical integrity and barrier properties. The incorporation of $C$. tomentosum $\mathrm{SE}$ in alginate films showed the potential to decrease their solubility and WVP, which would render a better scope of applications in the food industry, allowing the possibility of its application in products with higher moisture content (e.g., minimally-processed fruits). On the other hand, chitosan films with C. tomentosum SE were easier to prepare due to solubility increase and showed greater flexibility and 
resistance to mechanical forces, which may indicate the possibility of its use as a film in products with more flexible properties.

\section{Patents}

Portuguese National Patent No. 107369. "Marine coating for application in minimally processed products or IV range products". Augusto, A., Simões, T., Rodrigues, M.J., Campos, M.J., Leandro, S., Pedrosa, R., Silva, S.

Acknowledgments: This study had the support of Fundação para a Ciência e Tecnologia (FCT), through the strategic project UID/MAR/04292/2013 granted to MARE, and was partially supported by the projects CENTRO-07-0402-FEDER-23496 from the National Strategic Reference Framework (QREN), POCI-010247-FEDER-006392 through the COMPETE-Operational Competitiveness Programme and the project EASME/EMFF/2016/1.2.1.4/03/SI2.750419 by the European Maritime and Fisheries Fund, Action 1.2.1.4-Blue Labs: innovative solutions for maritime challenge. Ana Augusto wish to acknowledge the financial support given by FCT (SFRH/BD/131465/2017).

Author Contributions: S.F.J.S., M.J.C., N.M.A. and R.P. conceived and designed the experiments; A.A. and J.R.D. performed the experiments; A.A., J.R.D. and S.F.J.S. analysed the data; S.F.J.S., M.J.C., R.P. and N.M.A. contributed reagents/materials/analysis tools; and A.A., J.R.D., M.J.C., N.M.A., R.P. and S.F.J.S. wrote the paper.

Conflicts of Interest: The authors declare no conflict of interest.

\section{References}

1. Bourtoom, T. Edible films and coatings: Characteristics and properties. Int. Food Res. J. 2008, 15. [CrossRef]

2. Elsabee, M.Z.; Abdou, E.S. Chitosan based edible films and coatings: A review. Mater. Sci. Eng. C 2013, 33, 1819-1841. [CrossRef] [PubMed]

3. Galus, S.; Lenart, A. Development and characterization of composite edible films based on sodium alginate and pectin. J. Food Eng. 2013, 115, 459-465. [CrossRef]

4. Bierbrauer, K.L.; Alasino, R.V.; Muñoz, A.; Beltramo, D.M.; Strumia, M.C. Characterization and bacterial adhesion of chitosan-perfluorinated acid films. Colloids Surf. B. Biointerfaces 2014, 114, 201-208. [CrossRef] [PubMed]

5. Kurek, M.; Galus, S.; Debeaufort, F. Surface, mechanical and barrier properties of bio-based composite films based on chitosan and whey protein. Food Packag. Shelf Life 2014, 1, 56-67. [CrossRef]

6. Aider, M. Chitosan application for active bio-based films production and potential in the food industry: Review. LWT Food Sci. Technol. 2010, 43, 837-842. [CrossRef]

7. Hosseini, S.F.; Rezaei, M.; Zandi, M.; Ghavi, F.F. Preparation and functional properties of fish gelatin-chitosan blend edible films. Food Chem. 2013, 136, 1490-1495. [CrossRef] [PubMed]

8. Pereira, R.; Carvalho, A.; Vaz, D.C.; Gil, M.H.; Mendes, A.; Bártolo, P. Development of novel alginate based hydrogel films for wound healing applications. Int. J. Biol. Macromol. 2013, 52, 221-230. [CrossRef] [PubMed]

9. Valero, D.; Díaz-Mula, H.M.; Zapata, P.J.; Guillén, F.; Martínez-Romero, D.; Castillo, S.; Serrano, M. Effects of alginate edible coating on preserving fruit quality in four plum cultivars during postharvest storage. Postharvest Biol. Technol. 2013, 77, 1-6. [CrossRef]

10. Maizura, M.; Fazilah, A.; Norziah, M.; Karim, A. Antibacterial activity and mechanical properties of partially hydrolyzed sago starch—Alginate edible film containing lemongrass oil. J. Food Sci. 2007, 72, 324-330. [CrossRef] [PubMed]

11. Cian, R.E.; Salgado, P.R.; Drago, S.R.; González, R.J.; Mauri, A.N. Development of naturally activated edible films with antioxidant properties prepared from red seaweed Porphyra columbina biopolymers. Food Chem. 2014, 146, 6-14. [CrossRef] [PubMed]

12. Haddar, A.; Sellimi, S.; Ghannouchi, R.; Alvarez, O.M.; Nasri, M.; Bougatef, A. Functional, antioxidant and film-forming properties of tuna-skin gelatin with a brown algae extract. Int. J. Biol. Macromol. 2012, 51, 477-483. [CrossRef] [PubMed]

13. Gómez-Ordóñez, E.; Jiménez-Escrig, A.; Rupérez, P. Dietary fibre and physicochemical properties of several edible seaweeds from the northwestern Spanish coast. Food Res. Int. 2010, 43, 2289-2294. [CrossRef] 
14. Charoensiddhi, S.; Conlon, M.A.; Franco, C.M.M.; Zhang, W. The development of seaweed-derived bioactive compounds for use as prebiotics and nutraceuticals using enzyme technologies. Trends Food Sci. Technol. 2017, 70, 20-33. [CrossRef]

15. Gupta, S.; Abu-Ghannam, N. Recent developments in the application of seaweeds or seaweed extracts as a means for enhancing the safety and quality attributes of foods. Innov. Food Sci. Emerg. Technol. 2011, 12, 600-609. [CrossRef]

16. Valentão, P.; Trindade, P.; Gomes, D.; Pinho, P.G.; Mouga, T.; Andrade, P.B. Codium tomentosum and Plocamium cartilagineum: Chemistry and antioxidant potential. Food Chem. 2010, 119, 1359-1368. [CrossRef]

17. Andrade, P.B.; Barbosa, M.; Matos, R.P.; Lopes, G.; Vinholes, J.; Mouga, T.; Valentão, P. Valuable compounds in macroalgae extracts. Food Chem. 2013, 138, 1819-1828. [CrossRef] [PubMed]

18. Augusto, A.; Simões, T.; Pedrosa, R.; Silva, S.F.J. Evaluation of seaweed extracts functionality as post-harvest treatment for minimally processed Fuji apples. Innov. Food Sci. Emerg. Technol. 2016, 33, 589-595. [CrossRef]

19. AOAC International. Official Methods of Analysis of AOAC International, 17th ed.; AOAC International: Gaithersburg, MD, USA, 2000.

20. Bligh, E.G.; Dyer, W.J. A rapid method of total lipid extraction and purification. Can. J. Biochem. Physiol. 1959, 37, 911-917. [CrossRef] [PubMed]

21. Pinteus, S.; Silva, J.; Alves, C.; Horta, A.; Fino, N.; Rodrigues, A.I.; Mendes, S.; Pedrosa, R. Cytoprotective effect of seaweeds with high antioxidant activity from the Peniche coast (Portugal). Food Chem. 2017, 218, 591-599. [CrossRef] [PubMed]

22. Al-Hassan, A.A.; Norziah, M.H. Starch-gelatin edible films: Water vapor permeability and mechanical properties as affected by plasticizers. Food Hydrocoll. 2012, 26, 108-117. [CrossRef]

23. Abdollahi, M.; Alboofetileh, M.; Rezaei, M.; Behrooz, R. Comparing physico-mechanical and thermal properties of alginate nanocomposite films reinforced with organic and/or inorganic nanofillers. Food Hydrocoll. 2013, 32, 416-424. [CrossRef]

24. Phan, T.; Debeaufort, F.; Luu, D.; Voilley, A. Functional properties of edible agar-based and starch-based films for food quality preservation. J. Agric. Food Chem. 2005, 1, 973-981. [CrossRef] [PubMed]

25. ASTM. Standard Test Methods for Water Vapor Transmission of Materials. Annu. Book ASTM 1995, 552, 406-413.

26. Villalobos, R.; Hernández-Muñoz, P.; Chiralt, A. Effect of surfactants on water sorption and barrier properties of hydroxypropyl methylcellulose films. Food Hydrocoll. 2006, 20, 502-509. [CrossRef]

27. Siepmann, F.; Siepmann, J.; Walther, M.; MacRae, R.; Bodmeier, R. Aqueous HPMCAS coatings: Effects of formulation and processing parameters on drug release and mass transport mechanisms. Eur. J. Pharm. Biopharm. 2006, 63, 262-269. [CrossRef] [PubMed]

28. Blanco-Pascual, N.; Montero, M.P.; Gómez-Guillén, M.C. Antioxidant film development from unrefined extracts of brown seaweeds Laminaria digitata and Ascophyllum nodosum. Food Hydrocoll. 2014, 37, 100-110. [CrossRef]

29. The European Parliament and the Council of the European Union. DIRECTIVE 2009/32/EC of the European Parliament and of the Council of 23 April 2009 on the Approximation of the Laws of the Member States on Extraction Solvents Used in the Production of Foodstuffs and Food Ingredients. Available online: http:/ / eur-lex.europa.eu/LexUriServ/LexUriServ.do?uri=OJ:L:2009:141:0003:0011:EN:PDF (accessed on 28 March 2018).

30. Pereda, M.; Amica, G.; Marcovich, N.E. Development and characterization of edible chitosan/olive oil emulsion films. Carbohydr. Polym. 2012, 87, 1318-1325. [CrossRef]

31. Rattaya, S.; Benjakul, S.; Prodpran, T. Properties of fish skin gelatin film incorporated with seaweed extract. J. Food Eng. 2009, 95, 151-157. [CrossRef]

32. Koca, N.; Karadeniz, F.; Burdurlu, H.S. Effect of $\mathrm{pH}$ on chlorophyll degradation and colour loss in blanched green peas. Food Chem. 2007, 100, 609-615. [CrossRef]

33. Alboofetileh, M.; Rezaei, M.; Hosseini, H.; Abdollahi, M. Effect of montmorillonite clay and biopolymer concentration on the physical and mechanical properties of alginate nanocomposite films. J. Food Eng. 2013, 117, 26-33. [CrossRef]

34. Kannan, R.R.R.; Stirk, W.A.; Staden, J.V. Synthesis of silver nanoparticles using the seaweed Codium capitatum. S. Afr. J. Bot. J. 2013, 86, 1-4. [CrossRef] 
35. Lim, S.J.; Aida, W.M.W.; Maskat, M.Y.; Mamot, S.; Ropien, J.; Mohd, D.M. Isolation and antioxidant capacity of fucoidan from selected Malaysian seaweeds. Food Hydrocoll. 2014, 42, 280-288. [CrossRef]

36. Li, B.; Lu, F.; Wei, X.; Zhao, R. Fucoidan: Structure and bioactivity. Molecules 2008, 13, 1671-1695. [CrossRef] [PubMed]

37. Khuathan, N.; Pongjanyakul, T. Modification of quaternary polymethacrylate films using sodium alginate: Film characterization and drug permeability. Int. J. Pharm. 2014, 460, 63-72. [CrossRef] [PubMed]

38. Broderick, E.; Lyons, H.; Pembroke, T.; Byrne, H.; Murray, B.; Hall, M. The characterisation of a novel, covalently modified, amphiphilic alginate derivative, which retains gelling and non-toxic properties. J. Colloids Interface Sci. 2006, 298, 154-161. [CrossRef] [PubMed]

39. Jindal, M.; Kumar, V.; Rana, V.; Tiwary, A.K. Physico-chemical, mechanical and electrical performance of bael fruit gum-chitosan IPN films. Food Hydrocoll. 2013, 30, 192-199. [CrossRef]

40. Ying, G.; Xiong, W.; Wang, H.; Sun, Y.; Liu, H. Preparation, water solubility and antioxidant activity of branched-chain chitosan derivatives. Carbohydr. Polym. 2011, 83, 1787-1796. [CrossRef]

41. Peng, Y.; $\mathrm{Wu}, \mathrm{Y}$.; Li, Y. Development of tea extracts and chitosan composite films for active packaging materials. Int. J. Biol. Macromol. 2013, 59, 282-289. [CrossRef] [PubMed]

42. Benavides, S.; Villalobos-Carvajal, R.; Reyes, J.E. Physical, mechanical and antibacterial properties of alginate film: Effect of the crosslinking degree and oregano essential oil concentration. J. Food Eng. 2012, 110, 232-239. [CrossRef]

43. Norajit, K.; Kim, K.M.; Ryu, G.H. Comparative studies on the characterization and antioxidant properties of biodegradable alginate films containing ginseng extract. J. Food Eng. 2010, 98, 377-384. [CrossRef]

44. Silva-Pereira, M.C.; Teixeira, J.A.; Pereira-Júnior, V.A.; Stefani, R. Chitosan/corn starch blend films with extract from Brassica oleraceae (red cabbage) as a visual indicator of fish deterioration. LWT Food Sci. Technol. 2015, 61, 258-262. [CrossRef]

45. Seyedi, S.; Koocheki, A.; Mohebbi, M.; Zahedi, Y. Lepidium perfoliatum seed gum: A new source of carbohydrate to make a biodegradable film. Carbohydr. Polym. 2014, 101, 349-358. [CrossRef] [PubMed]

46. Houghton, P.J.; Raman, A. Laboratory Handbook for the Fractionation of Natural Extracts, 1st ed.; Springer: Boston, MA, USA, 1998.

47. Ma, Q.; Zhang, Y.; Zhong, Q. Physical and antimicrobial properties of chitosan films incorporated with lauric arginate, cinnamon oil, and ethylenediaminetetraacetate. LWT Food Sci. Technol. 2016, 65, 173-179. [CrossRef]

48. Vieira, M.G.A.; Silva, M.A.; Santos, L.O.; Beppu, M.M. Natural-based plasticizers and biopolymer films: A review. Eur. Polym. J. 2011, 47, 254-263. [CrossRef]

49. Jridi, M.; Hajji, S.; Ayed, H.B.; Lassoued, I.; Mbarek, A.; Kammoun, M.; Souissi, N.; Nasri, M. Physical, structural, antioxidant and antimicrobial properties of gelatin-chitosan composite edible films. Int. J. Biol. Macromol. 2014, 67, 373-379. [CrossRef] [PubMed]

50. Souza, B.W.S.; Cerqueira, M.A.; Martins, J.T.; Casariego, A.; Teixeira, J.A.; Vicente, A.A. Influence of electric fields on the structure of chitosan edible coatings. Food Hydrocoll. 2010, 24, 330-335. [CrossRef]

51. Bourbon, A.I.; Pinheiro, A.C.; Cerqueira, M.A.; Rocha, C.M.R.; Avides, M.C.; Quintas, M.A.C.; Vicente, A.A. Physico-chemical characterization of chitosan-based edible films incorporating bioactive compounds of different molecular weight. J. Food Eng. 2011, 106, 111-118. [CrossRef]

52. Carneiro-da-Cunha, M.G.; Cerqueira, M.A.; Souza, B.W.S.; Carvalho, S.; Quintas, M.A.C.; Teixeira, J.A.; Vicente, A.A. Physical and thermal properties of a chitosan/alginate nanolayered PET film. Carbohydr. Polym. 2010, 82, 153-159. [CrossRef]

53. Rodriguez-Jasso, R.M.; Mussatto, S.I.; Pastrana, L.; Aguilar, C.N.; Teixeira, J.A. Microwave-assisted extraction of sulfated polysaccharides (fucoidan) from brown seaweed. Carbohydr. Polym. 2011, 86, 1137-1144. [CrossRef]

54. Rodríguez-Spong, B.; Price, C.P.; Jayasankar, A.; Matzger, A.J.; Rodríguez-Hornedo, N. General principles of pharmaceutical solid polymorphism: A supramolecular perspective. Adv. Drug Deliv. Rev. 2004, 56, $241-274$. [CrossRef] [PubMed]

(C) 2018 by the authors. Licensee MDPI, Basel, Switzerland. This article is an open access article distributed under the terms and conditions of the Creative Commons Attribution (CC BY) license (http:/ / creativecommons.org/licenses/by/4.0/). 